\title{
The long bone histology of Ceresiosaurus (Sauropterygia, Reptilia) in comparison to other eosauropterygians from the Middle Triassic of Monte San Giorgio (Switzerland/Italy)
}

\author{
Jasmina Hugi
}

Received: 27 May 2011/Accepted: 9 August 2011/Published online: 30 August 2011

(C) Akademie der Naturwissenschaften Schweiz (SCNAT) 2011

\begin{abstract}
Ceresiosaurus is a secondarily marine reptile that lived during the Middle Triassic (Ladinian-Anisian) in a subtropical lagoonal environment with varying open marine influences. The genus comprises two species, Ceresiosaurus calcagnii and C. lanzi, and represents one of the largest vertebrate of up to 3-m snout-tail length from the UNESCO World Heritage site Monte San Giorgio, which is settled along the Swiss-Italian border. Earlier morphological studies identified this genus as basal sauropterygian still possessing many similarities with the plesiomorphic ancestral terrestrial condition. Interspecific morphological variation was interpreted as indicator for different habit(at) preferences by ascribing two locomotion types for each of the species. In this study, detailed data on the microstructure of the long bones are given and findings were put into a palaeoecological and phylogenetic context in comparison to other sauropterygians from Monte San Giorgio. Results showed that both Ceresiosaurus species retain a calcified cartilaginous core in the medullary region in at least young individuals. They both exhibit cyclical bone growth of lamellar to parallel-fibred bone matrices with undulating incremental growth marks and low to moderate vascularisation (lamellar-zonal bone tissue type). Interspecific variation comprises differences in the distribution of differently organised bone matrices and the size, orientation and number of vascularisation. The vascularisation pattern (abundance and orientation of the canals) of the pachyosteosclerotic long bones of $C$. calcagnii mostly resembles the histotype of the stratigraphically youngest pachypleurosaurid from Monte San Giorgio, Neusticosaurus edwardsii
\end{abstract}

\footnotetext{
J. Hugi $(\bowtie)$

Paleontological Institute and Museum, University Zurich,

Karl-Schmid Straße 4, 8006 Zurich, Switzerland

e-mail: jasmina.hugi@pim.uzh.ch
}

(except for the presence of primary osteons in the cortex of the former). The bone sample of C. lanzi is only osteosclerotic and most similar to young Nothosaurus (except for the irregular presence of fibrolamellar bone in the latter). The slightly different growth pattern already at young ontogenetic stages might be linked to a different mode of life within the restricted lagoonal basin for Ceresiosaurus, which supports previous studies on the morphological data that ascribed two different locomotion types.

Keywords Eosauropterygia - Switzerland/Italy · Triassic $\cdot$ Bone histology $\cdot$ Lifestyle

\section{Introduction}

Sediments of the Middle Triassic of Monte San Giorgio, a UNESCO World Heritage Site located along the Swiss and Italian borders, have yielded eight excellently preserved specimens of a rather large secondarily aquatic reptile with the genus name Ceresiosaurus, 'the lizard of Lugano' (Peyer 1931, 1932). The genus Ceresiosaurus comprises different ontogenetic stages of two species, C. calcagnii PEYER (Peyer 1931) and C. lanzi HÄNNI (Hänni 2004), which are both known from the Lower Meride Limestone (Peyer 1931; Bürgin et al. 1989; Furrer 1995; Hänni 2004). Ceresiosaurus calcagnii has been found in the Cava superiore and Cava inferiore beds, whereas $C$. lanzi has been preserved only in the stratigraphically younger Cassina beds (Peyer 1931; Bürgin et al. 1989; Furrer 1995; Hänni 2004). Ceresiosaurus spp. are basal sauropterygians (e.g. Rieppel 2000; Müller et al. 2010; Fig. 1) that lived in subtropical marine environments of the Tethys (e.g. Parrish et al. 1982; Röhl et al. 2001). Facies analyses revealed decreasing open marine influences based on an increasing restriction of the 
basin towards the open sea during the sedimentation of Cava superiore, Cava inferiore beds and Cassina beds (e.g. Parrish et al. 1982; Röhl et al. 2001). Morphological differences studied by Hänni (2004) accredited an evolutionary trend of two locomotion types for each species, interpreted as different habitat preferences within the restricted lagoonal environment. The stratigraphically older C. calcagnii is described as an axial to paraxial swimmer based on a massive pectoral girdle, a long tail with high neural arches in the anterior caudal vertebrae and pachyostosis in the ribs of the trunk. The adult morphology of the stratigraphically younger $C$. lanzi was proposed to be a quicker pelagic swimmer based on the development of solely paraxial locomotion, which is indicated by the absence of pachyostotic ribs of the trunk and a shorter tail with vertebrae without high neural arches (Hänni 2004). Therefore, $C$. calcagnii moved using a combination of axial undulation and propulsion with the paired appendages, whereas the locomotion of the stratigraphically younger C. lanzi was exclusively based on the latter. The investigation of the morphology of the microstructure of the bone (bone histology) might reveal further support for these two different modes of life in the two Ceresiosaurus species.

Bone histology is a comparative approach to study the life history of extant and extinct vertebrates. It is based on the individual's growth record and can indicate the life history by reflecting function (e.g. locomotion), ecology (e.g. habitat) and/or phylogeny (e.g. Castanet et al. 1993; Wiffen et al. 1995; Sheldon 1997; Cubo et al. 2005; Cubo et al. (2008); Klein 2010; Scheyer et al. 2010). There are several trends in the bone microstructure, which are shared in secondarily aquatic tetrapods with similar lifestyles (e.g. Buffrénil and Schoevaert 1988; Germain and Laurin 2005; Canoville and Laurin 2010; Houssaye 2010). Tetrapods which secondarily adapted to shallow marine environments often show very dense long bones (Ricqlès and Buffrénil 2001) in which they are considered to play the functional role of ballast for hydrostatic regulation of the body trim (Taylor 2000). An increased bone density can be achieved by the inhibition of resorption processes along the inner wall of the cortex and/or a continuous deposition of primary bone material along the outer wall of the cortex that leads to a hyperplasy of the cortex (i.e. pachyostosis). Pachyostosis is also visible from an external view as already observed in the ribs of $C$. calcagnii. The medullary region can reveal higher bone density by an incomplete endochondral ossification (i.e. retention of a calcified cartilaginous core in the medullary region) and/or by remodelling processes (i.e. osteosclerosis; after Ricqlès and Buffrénil 2001; Houssaye 2010). The combination of pachyostosis and osteosclerosis is summarised as pachyosteosclerosis, which has been noted for "Ceresiosaurus" by Ricqlès and Buffrénil (2001) without further specific or histological information. Another trend in bond histology of secondarily aquatic tetrapod taxa is developed in quick pelagic swimmers in open marine environments, as exemplified by extant cetaceans (e.g. Buffrénil and Schoevaert 1988) and extinct ichthyosaurs (e.g. Buffrénil and Mazin 1990; Kolb et al. 2011). They display an osteoporotic-like condition that results from an inner reduction in bone volume due to a higher primary vascularisation and/or more remodelling processes in the cortex (Ricqlès and Buffrénil 2001). Osteoporotic-like bones are also observed in adult individuals of some sauropterygians, whereas their younger ontogenetic stages show (pachy)osteosclerosis (Wiffen et al. 1995; Krahl et al. 2009; Klein 2010). Quick swimming pelagic sauropterygians (pistosauroids) that survived into the Jurassic all show fibrolamellar bone tissue type in the cortex, which might be equalised with their successful global radiation (Klein 2010). Fibrolamellar bone tissue type is, in contrast to the lamellar-zonal bone tissue type, accompanied with increased growth rates and presumably even with increased metabolic rates (Ray et al. 2004; Ricqlès et al. 2008; Stein and Langer 2009). However, a recent study on the bone histology in eosauropterygians pushes the origin of fibrolamellar bone in Sauropterygia back to the early Middle Triassic (early Anisian), with abundant fibrolamellar bone throughout the cortex of not only pistosauroids, but also of one pachypleurosaurid A. heterodontus. An irregular deposition of fibrolamellar bone has also been preserved in Nothosaurus (Klein 2010).

In this study, detailed data on the microstructure of the long bones is given for the rare material of the genus Ceresiosaurus for placing the findings in a palaeoecological and phylogenetic context with comparison to Nothosaurus and the pachypleurosaurids from Monte San Giorgio (Fig. 1).

\section{Materials and methods}

Five isolated long bones of three specimens of Ceresiosaurus were used for thin sectioning (Table 1). One element is assigned to $C$. lanzi and two elements belong to C. calcagnii, whereas the rest is of uncertain species relationship (Table 1). The material which was available for processing thin sections is housed in the Paleontological Institute of the University of Zurich (PIMUZ). Thin sections of the mid-shaft region of the long bones were processed and documented at the PIMUZ, following standard petrographic preparation techniques (e.g. Chinsamy and Rath 1992). The diaphyseal region of the limb bones is known to yield the strongest ecological signal (Canoville and Laurin 2010) and generally preserves the most complete growth record of the bones among vertebrates 
Table 1 Measurements of the bone samples of Ceresiosaurus calcagnii and $C$. lanzi, which were available for processing thin sections

\begin{tabular}{l} 
Specimen \\
\hline C. lanzi \\
T5454 \\
C. calcagnii \\
T5153 (belongs to T5152) \\
$\mathrm{T} 5152$ \\
$\mathrm{~T} 5622$ \\
$\mathrm{~T} 5622$
\end{tabular}

Question marks indicate that the bone sample is not entirely preserved. The value of the width $(W)$ refers to the anteroposterior distance of the long bones at the area where the thin sections were processed. The lengths ( $L$ proximodistal length of the limb bones or the dorsoventral length of ribs) of the two adult reference species are given in brackets (for C. calcagnii: T4836 and for C. lanzi: T2464, from Hänni 2004). The rib lengths in brackets refer to the maximum length of the trunk ribs within one of those two adult reference species

(Francillon-Vieillot et al. 1990). The comparison of rib bones and limb bones is problematic because rib growth mainly involves drift which absorbs the previously deposited growth record. The bone histology based on rib samples is therefore more reluctant to sampling bias. However, the study by Waskow and Sander (2011) showed that ribs revealed the most complete growth record near the rib head. Histological data comprise the description of bone tissue types that are composed of bone matrices with a specific vascularisation pattern and organisation of the crystallites. The bone density was also quantitatively analysed (Table 2) using the PC Version of the program Bone Profiler (Girondot and Laurin 2003). The images were prepared using Adobe Photoshop CS3 and Adobe Illustrator CS3 (Fig. 1).

\section{Histological abbreviations}

cc Calcified cartilaginous core

co Cortex

ed. Endosteal infilling of vascular canals in the medullary region

efs External fundamental system (Horner et al. 2001)

$\mathrm{flb}$ Fibrolamellar bone tissue type

med Medullary region

lags Lines of arrested growth (Francillon-Vieillot et al. 1990)

lb Lamellar bone matrix

lzb Lamellar-zonal bone tissue type

O.c. Observed compactness (Girondot and Laurin 2003)

pfb Parallel-fibred bone matrix $\begin{array}{ll}\text { po } & \text { Primary osteon } \\ \text { so } & \text { Secondary osteon }\end{array}$

svc Simple primary vascular canals

wb Woven-fibred bone matrix

\section{Results}

Long bone histology of Ceresiosaurus

Ceresiosaurus shows the plesiomorphic lamellar-zonal bone tissue type in the cortex of the long bones. The bone matrix consists of lamellar and parallel-fibred bone, which is vascularised by a low to moderate number of simple radial and longitudinal vascular canals, as well as primary osteons of the same orientation. The growth cycles are regularly distributed and consist of undulating bone layers that are bordered by lags, which are in some cases subannually deposited (i.e. supernumerary lags; Zug and Rand 1987). One layer of embryonic woven-fibred bone is deposited as the innermost cortical region adjacent to the calcified cartilaginous core in the limb bone samples, whereas the rib samples exhibit no comparable inner layer. The layer of woven-fibred bone is opaque in polarised light and characterised by a high number of simple longitudinal primary vascular canals and a high abundance of round osteocyte lacunae. The innermost periosteal growth layers are entirely preserved, as no or only minor resorption occurs along the border between the cortex and the medullary region (Fig. 2). In all long bones of Ceresiosaurus, 
Table 2 Compactness parameters given by the program Bone Profiler (Girondot and Laurin 2003), global analysis

\begin{tabular}{|c|c|c|c|c|c|c|c|}
\hline Specimen & Element & O.c. & $S(\mathrm{SE})$ & $P(\mathrm{SE})$ & $\operatorname{Min}(\mathrm{SE})$ & $\operatorname{Max}(\mathrm{SE})$ & $R^{2}$ \\
\hline \multicolumn{8}{|l|}{ C. lanzi } \\
\hline T5454 & Trunk rib & 0.942 & $\begin{array}{l}0.5763385 \\
\quad(0.0244667)\end{array}$ & $-0.3312575(0)$ & $0.7589635(0)$ & $0.9768501(0)$ & 0.2222631 \\
\hline \multicolumn{8}{|l|}{ C. calcagnii } \\
\hline $\begin{array}{l}\text { T5153 (belongs to } \\
\text { T5152) }\end{array}$ & Trunk rib & 0.958 & $0.1363788(0)$ & $\begin{array}{l}-1.121276 \\
(0.0019849)\end{array}$ & $273.8826(0)$ & $0.9548898(0)$ & 0.2924631 \\
\hline T5152 & Tibia & 0.942 & $\begin{array}{l}0.5763595 \\
\quad(0.0578412)\end{array}$ & $\begin{array}{r}-0.311316 \\
(0.726452)\end{array}$ & $\begin{array}{l}0.7644133 \\
\quad(0.1724227)\end{array}$ & $\begin{array}{l}0.9769729 \\
(0.004843)\end{array}$ & 0.221034 \\
\hline T5622 & Femur & 0.938 & $\begin{array}{l}0.0017743 \\
(0.000133)\end{array}$ & $\begin{array}{l}0.2525645 \\
\quad(0.0002465)\end{array}$ & $\begin{array}{l}0.7997667 \\
\quad(0.0010975)\end{array}$ & $\begin{array}{l}0.9481725 \\
\quad(0.0001502)\end{array}$ & 0.5504299 \\
\hline T5622 & Trunk rib & 0.983 & $\begin{array}{l}0.5492734 \\
\quad(0.2268195)\end{array}$ & $\begin{array}{l}-2.120804 \\
(0.8443007)\end{array}$ & $1.00 \mathrm{e}-06(0)$ & $\begin{array}{l}0.989741 \\
(0.0032301)\end{array}$ & 0.03123 \\
\hline \multicolumn{8}{|l|}{ Nothosaurus } \\
\hline AIII 0002 & Humerus & 0.354 & $\begin{array}{l}0.0949361 \\
\quad(0.0003145)\end{array}$ & $\begin{array}{l}0.8464544 \\
(0.0003001)\end{array}$ & $\begin{array}{l}0.0924207 \\
\quad(0.0005443)\end{array}$ & $\begin{array}{l}0.999999 \\
\quad(4.282764 \mathrm{e}-6)\end{array}$ & 0.9701097 \\
\hline AIII 0001 & Femur & 0.299 & $\begin{array}{l}0.0549727 \\
(0.0001028)\end{array}$ & $\begin{array}{l}0.84699 \\
(0.0001402)\end{array}$ & $\begin{array}{l}0.0313348 \\
(0.0001911)\end{array}$ & $\begin{array}{l}0.999999 \\
\quad(2.60317 \mathrm{e}-6)\end{array}$ & 0.9943773 \\
\hline
\end{tabular}

The observed compactness (O.c.) is comparable to other secondarily aquatic reptiles with pachyosteosclerotic bones (e.g. Hugi et al. 2011). The parameters are given as supplementary information, but are not representative because the specimens are of young ontogenetic age and later changes in the bone microstructure are expected, but hence, unknown (Wiffen et al. 1995; Klein 2010; Kolb et al. 2011). Please note that the minimum value of the rib of T5153 is not reliable. In this case, the model explains little, but may reflect the high overall compactness of this thin section. The variances $\left(R^{2}\right)$ of Ceresiosaurus are low, but not necessarily unreliable. In all sections, the compactness profiles are high and values are only lowered locally by the presence of erosion cavities and vascular canals in the medullary region and the cortex (see $S$ value in some cases) $S$ starting point, $S E$ standard deviation, $P$ the distance to the centre where the most abrupt change of compactness is observed, Min minimal value measured, Max maximal value measured

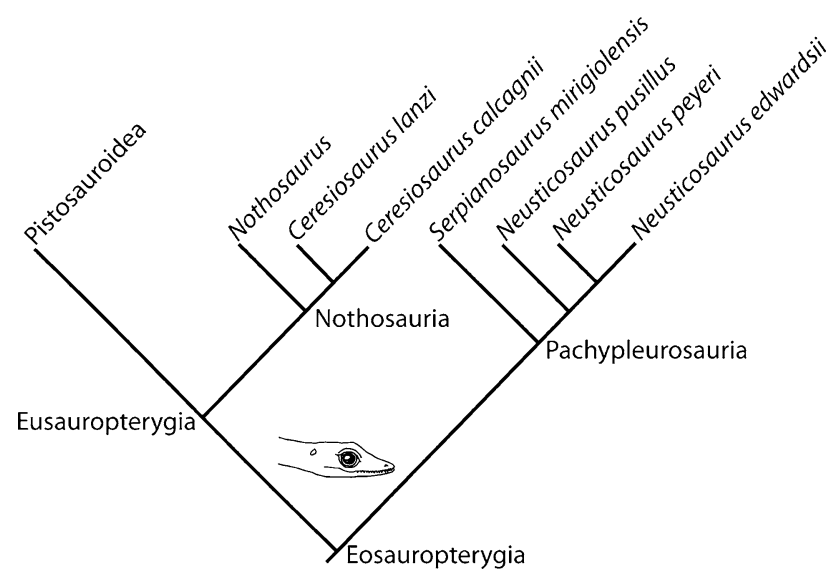

Fig. 1 Phylogeny of eosauropterygia (after Sander 1989; Rieppel 2000). The species names and in one case the genus name are given for eosauropterygians included in the study

the medullary region is entirely filled with calcified cartilage that persists as the main component in at least juvenile to subadult individuals and results in high minimal compactness values ranging from 0.76 to 0.80 (Fig. 2; Table 2). All samples show remodelling processes in the calcified cartilage, which are either erosion cavities or widened simple vascular canals that are refilled with centripetally deposited endosteal lamellar bone layers (Fig. 2). The global analysis of the compactness displays high and constant compactness profiles based on the persistence of the calcified cartilaginous core and minor remodelling of the inner wall of the cortex (Table 2). The compactness values are only locally lowered by erosion cavities and vascular canals in both the medullary and cortical region. None of the bone samples shows an indicator that sexual maturity (i.e. a change in the organisation of the bone matrix and vascularisation pattern, thickness of the growth cycles after Castanet et al. 1993) was reached or that the growth of an individual was terminated (efs sensu Horner et al. 2001).

Differences in the bone samples that were identified to species level are expressed through: variation in the (1) abundance and orientation of the vascular canals of the cortex, and in the (2) amount of the two preserved bone matrices (lamellar bone matrix vs. parallel-fibred bone matrix). Ceresiosaurus calcagnii shows a rather thick cortex contrary to the thinner cortex with a relatively large medullary region of $C$. lanzi of approximately equivalent ontogenetic age. C. lanzi, in contrast, shows slightly higher bone compactness values than $C$. calcagnii (Figs. 2, 3; Table 2). 

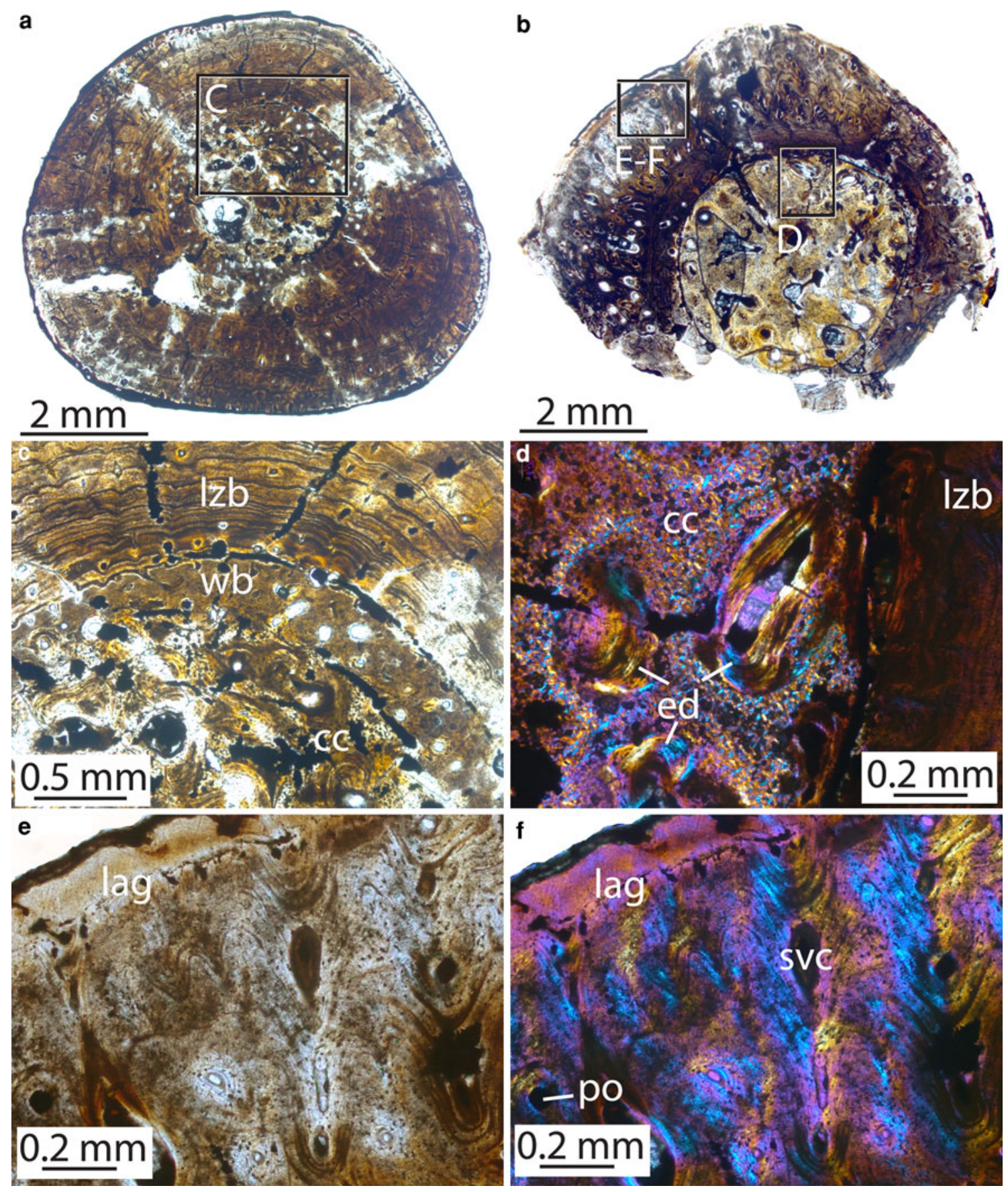

Fig. 2 The microstructure of the long bones of Ceresiosaurus. Transverse mid-shaft section of a the pachyosteosclerotic femur of C. calcagnii (T5622) and b the osteosclerotic trunk rib of $C$. lanzi (T5454). c Higher magnification of the femur of $C$. calcagnii. The inner periosteal cortical region comprises a layer of embryonic bone that is composed of woven-fibred bone $(w b)$. The thick cortex consists of lamellar-zonal bone tissue type $(l z b)$ with undulating growth zones,

The stratigraphical older $C$. calcagnii predominantly shows long, radial simple vascular canals and primary osteons and less longitudinally orientated vascularisation (Figs. 2, 3). The bone matrix of $C$. lanzi, in contrast, consists of a higher

annuli and lags. d-f Higher magnifications of the rib sample of C. lanzi. d The medullary cavity is filled with a calcified cartilaginous core $(c c)$ that is remodelled by resorption and deposition of endosteal bone $(e d)$. e, $\mathbf{f}$ The crystallites around the vascular canals are aligned in funnel-shaped arrangements (e in normal light and $\mathbf{f}$ in polarised light with lambda compensator). Further abbreviations: po primary osteon, svc simple vascular canal

amount of parallel-fibred bone tissue with a higher number of scattered, but relatively wide, longitudinally orientated simple vascular canals, primary osteons and at least one isolated secondary osteon in the cortex (Fig. 2). 
Fig. 3 Black and white sketches of the transverse mid-shaft sections of the long bones of several sauropterygians from Monte San Giorgio. a femur of Serpianosaurus mirigiolensis (T105, O.c.: 0.984 from Hugi et al. 2011), b femur of Neusticosaurus edwardsii (T3437, O.c.: 0.958 from Hugi et al. 2011), c femur of Ceresiosaurus calcagnii (T5622; O.c.: 0.938), d rib of Ceresiosaurus lanzi (T5454; O.c.: 0.942), e femur of Nothosaurus (AIII 0001; O.c.: 0.299). Stippled line reconstructed outline of the outer wall of the cortex $(\mathrm{co})$; red, continuous line outline of the medullary region/cavity (med); O.c. observed compactness (see Table 2)
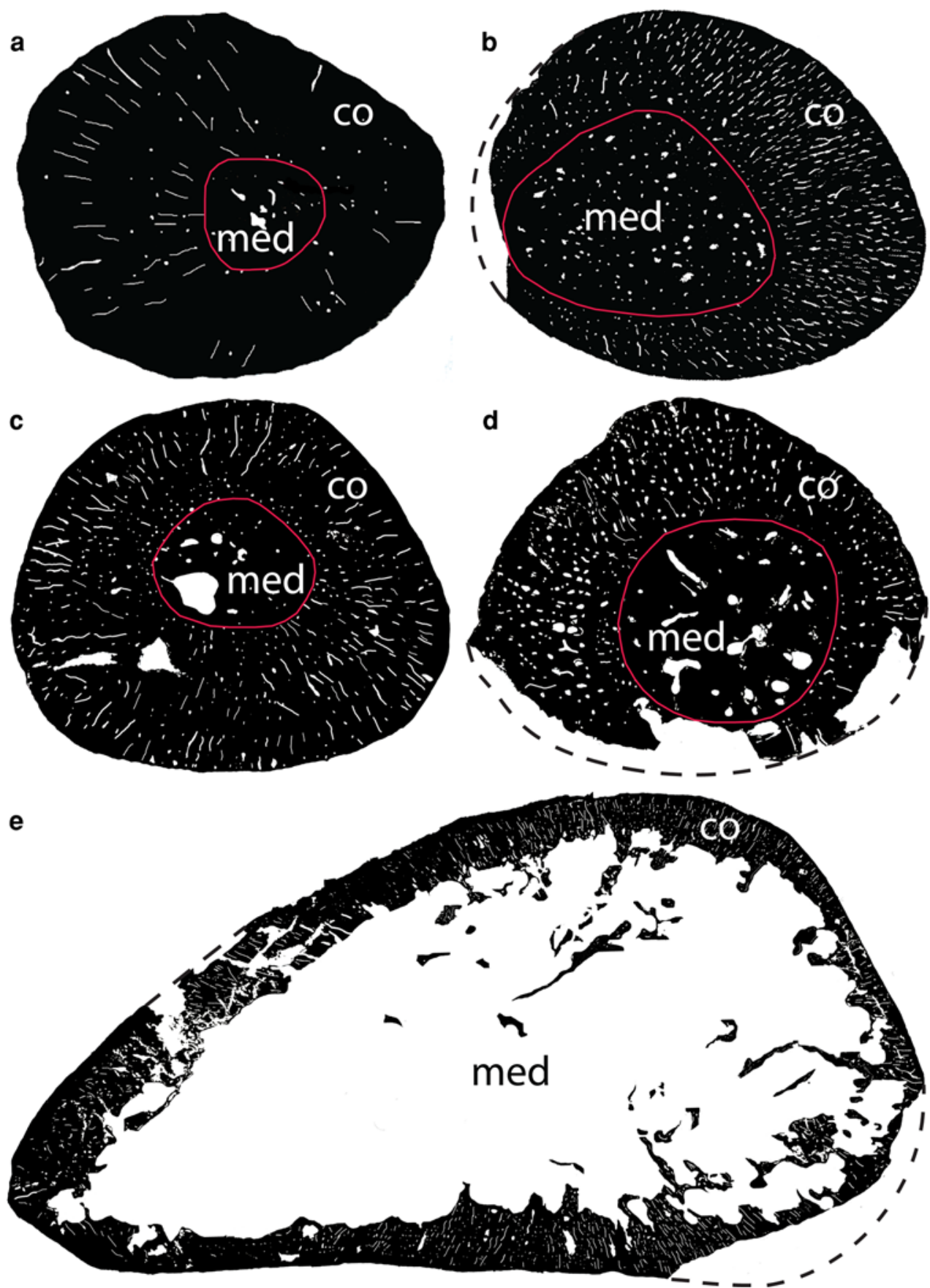

\section{Discussion}

Comparison to other Nothosauria: Nothosaurus of the Upper Muschelkalk

Ontogenetically old Nothosaurus specimens show very thin cortices of predominantly lamellar-zonal bone tissue type surrounding a large medullary cavity filled with trabeculae as remains of the resorption process of the inner cortical growth record during the ontogeny (Krahl et al. 2009). The bands of the lamellar bone and parallel-fibred bone matrices are irregularly intercalated with phases of fibrolamellar bone tissue type in Nothosaurus (Figs. 4, 5). The spacing pattern of the lags is variable (Klein 2010). Ontogenetically young individuals show a calcified cartilaginous core that often infills the entire medullary region (Krahl et al. 2009). Therefore, Nothosaurus from the Germanic Basin shows an ontogenetic shift from an osteosclerotic to a lighter, "osteoporotic-like" bone structure that is interpreted as an adaptation to an increasingly pelagic habitat with paraxial locomotion in more open marine environments (e.g. Krahl et al. 2009). The bone 

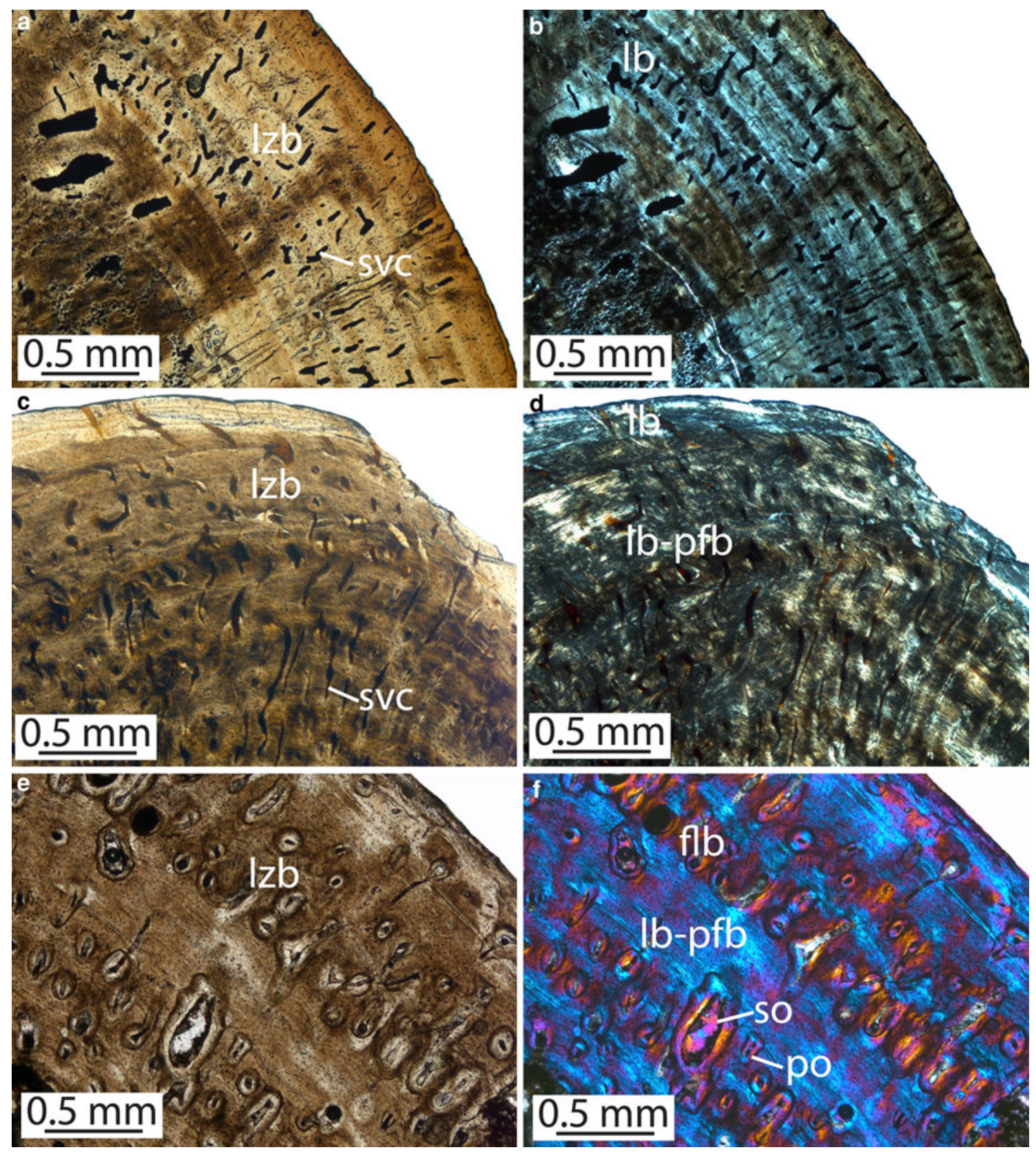

Fig. 4 The cortical growth pattern of Serpianosaurus mirigiolensis (a, b), Neusticosaurus edwardsii (c, d) from Monte San Giorgio and Nothosaurus (e, f) from the Germanic Basin. All show lamellar-zonal bone tissue type $(l z b)$ with a varying growth pattern. The bone matrix of the cortex of $S$. mirigiolensis comprises lamellar bone $(l b)$ with simple vascular canals $(s v c)$. N. edwardsii shows parallel-fibred

compactness value of $0.299-0.354$ of the global analysis achieved by Bone Profiler (Table 2; Fig. 3; Germain and Laurin 2005) further supports a quick swimming mode. The bone sample of the ontogenetically young Ceresiosaurus lanzi resembles the histotype of young Nothosaurus. Nothosaurus bones are only fragmentarily preserved in the sediments of Monte San Giorgio (e.g. Rieppel 2001), which might be linked to the fact that they presumably $(p f b)$ and lamellar bone $(l b)$ with the same vascularisation like S. mirigiolensis, whereas the cortex of Nothosaurus is classified as lamellar-zonal bone $(l z b)$, which is irregularly interrupted by bands of fibrolamellar bone $(f b)$. The vascularisation comprises primary ( $p o$ ) and secondary osteons (so)

lived in open marine environments as also indicated by morphological and histological data.

\section{Comparison to Pachypleurosauria from Monte San Giorgio}

Four pachypleurosaurid species have been found in sediments of Monte San Giorgio ranging from 25 to 


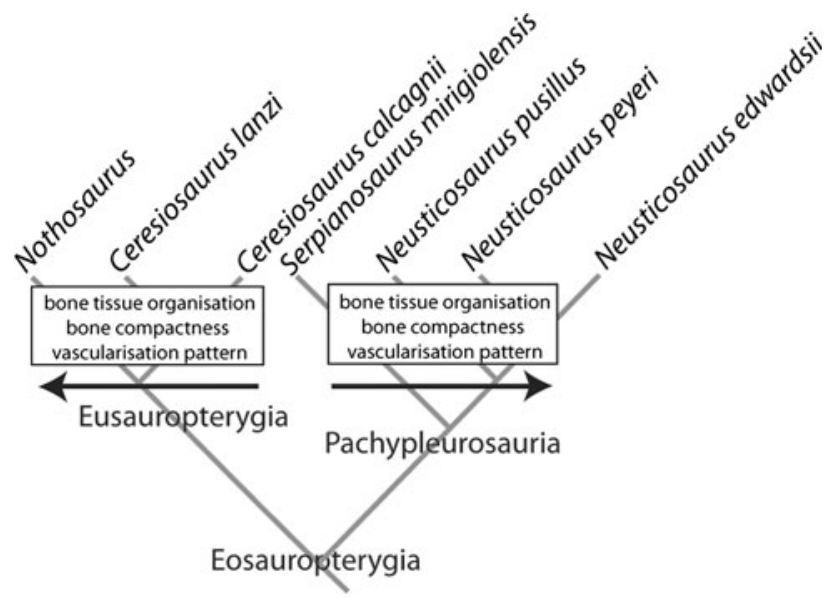

Fig. 5 Summary of the results of the bone histological analysis: Eusauropterygia and Pachypleurosauria revealed similar trends within their branches, which are indicated by arrows. The pachypleurosaurids decrease the (1) organisation of the crystallites (bone tissue organisation), as well as the (2) bone compactness values with stratigraphical age (Hugi et al. 2011). Bone compactness values only decrease slightly with stratigraphical age based on the greater number of simple vascular canals in the cortex (vascularisation pattern). The orientation of the vascularisation (vascularisation pattern) changes from predominantly longitudinally orientated ones in $S$. mirigiolensis to predominantly radially orientated ones in the cortex of N. edwardsii (Hugi et al. 2011). A similar trend is observed in Nothosauria: the cortex of C. calcagnii shows an overall higher organisation of the bone matrix with a higher number of radially orientated simple vascular canals and primary osteons, whereas $C$. lanzi shows a higher amount of less organised bone matrix $(p f b)$ with a greater number of longitudinally orientated primary osteons and simple vascular canals of wider diameter. The bone compactness value of ontogenetically young $C$. calcagnii and $C$. lanzi is slightly higher in the latter in relation to the bone samples of the former. The compactness values of Nothosaurus are lower based on a wider diameter of the medullary cavity and a higher abundance of vascularisation in the cortex (simple vascular canals, primary osteons and secondary osteons). The bone matrix of the cortex additionally consists of fibrolamellar bone tissue type in relation to the exclusive presence of lamellar-zonal bone tissue type in the other eosauropterygians from Monte San Giorgio

approximately $120 \mathrm{~cm}$ snout-tail lengths in adults. The stratigraphically oldest taxon Serpianosaurus mirigiolensis is exclusively found in sediments of the Besano Formation (former Grenzbitumen beds; e.g. Carroll and Gaskill 1985). The stratigraphically younger genus Neusticosaurus is preserved in the same beds as Ceresiosaurus spp., the Cava inferiore, Cava superiore, as well as the Cassina beds (Sander 1989; Rieppel 1989). They all show osteosclerosis and a varying degree of pachyostosis in the long bones (Zangerl 1935; Ricqlès 1976; Hugi et al. 2011). During the ontogeny, the calcified cartilaginous core is partially, or in one species even entirely, replaced at the diaphyseal and/or metaphyseal region by endosteally deposited bone (e.g. Hugi et al. 2011). The stratigraphically well separated pachypleurosaurid species show similarities, but also differences in their long bone histology most possibly reflecting different modes of life (S. mirigiolensis and N. edwardsii: quicker swimmer; $N$. pusillus and $N$. peyeri: slower swimmer, but more demersal?; Hugi et al. 2011). All pachypleurosaurids show plesiomorphic lamellar-zonal bone tissue type throughout the cortex (Figs. 4, 5). The cortex of the bones of S. mirigiolensis consists of alternating bands of lamellar bone, whereas these bands comprise both parallel-fibred and lamellar bone matrices in the Neusticosaurus species, with the stratigraphically youngest pachypleurosaurid $N$. edwar$d s i i$ showing the highest amount of parallel-fibred bone in its cortex. The crystallites around the simple vascular canals show a funnel-shaped arrangement in $N$. edwardsii and locally overlap with each other, producing the impression of a patchy presence of woven-fibred bone (Hugi et al. 2011; Fig. 4). This impression is also present in the Ceresiosaurus samples (Fig. 2f). Long bones of $C$. calcagnii resemble the histotype of $N$. edwardsii regarding the thick cortex and the predominant presence of radially orientated vascular canals. Contrary to the exclusive simple vascularisation in $N$. edwardsii, the long bones of $C$. calcagnii further contain primary osteons, but the number of vascularisation is lower than in N. edwardsii (Fig. 3). Ceresiosaurus lanzi shares the abundant presence of parallel-fibred bone with N. edwardsii, but differs in the vascularisation pattern from both $N$. edwardsii and $C$. calcagnii. In young $C$. lanzi, the simple vascular canals and primary osteons are predominantly longitudinally arranged and wider in size than in C. calcagnii and N. edwardsii. The young ontogenetic stage of the only C. lanzi sample shows no pachyostosis, but osteosclerosis.

\section{Comparison to basal Pistosauroidea}

All of the discussed eosauropterygians are Nothosauroidea which show lamellar-zonal bone tissue type and in one case the irregular presence of fibrolamellar bone tissue type (Figs. 4, 5). In contrast, in basal and derived members of the Pistosauroidea, fibrolamellar bone is the dominating bone tissue type (e.g. Wiffen et al. 1995; Klein 2010). The presence of lamellar-zonal bone tissue type generally reflects slow growth rates and, therefore, might also indicate low metabolic rates, whereas the frequent presence of fibrolamellar bone tissue type is a result of quick growth rates in vertebrates of higher metabolic rates (e.g. Horner et al. 2000; Padian et al 2001). As indicated by Klein (2010), continuous higher metabolic rates might be responsible for the ability of pistosauroids to spread over the Tethys by also conquering colder sea regions.

\section{Conclusion}

Data on the long bone histology partly support the evolutionary trend of two different modes of locomotion in 
C. calcagnii and $C$. lanzi based on morphological studies (Hänni 2004). The bone sample of $C$. calcagnii shows pachyosteosclerotic long bones similarly to $N$. edwardsii. The orientation, size and abundance of vascular canals of C. calcagnii are also similar to the data of $N$. edwardsii (except for the fact that the former further displays primary osteons in the cortex). The rib sample of $C$. lanzi is osteosclerotic and reveals a different growth pattern with wider vascular canals in an overall less organised bone matrix. However, compactness profiles of both Ceresiosaurus spp. are high and the minimal values range between 0.76 and 0.80 , which does not indicate a quick swimming mode for any of the two species at this presumably juvenile stage of ontogeny (Germain and Laurin 2005). Further information on the growth pattern during the subsequent ontogeny of Ceresiosaurus remains unknown. It is reported that at least the rib bones of $C$. calcagnii remain pachyostotic. However, based on the close resemblance of the histotype of $N$. edwardsii, it is likely that the adult histotype also retains the osteosclerotic condition. The adult histotype of $C$. lanzi could either remain osteosclerotic or become osteoporotic as in adult Nothosaurus.

Acknowledgments I would like to thank all the members of the Sánchez' laboratory and especially T. Scheyer and M. SánchezVillagra for the helpful discussion on earlier versions of the manuscript. This work would have never been possible without the permission of $\mathrm{H}$. Furrer for processing the thin sections of the sampled Ceresiosaurus specimens. K. Stein and M. Laurin who reviewed the manuscript helped to improve the quality. I am especially thankful to M. Laurin, because he helped with the interpretation of the parameters of Bone Profiler and reanalysed the data. This project was funded by the Swiss National Science Foundation Grant No. 31003A-133032/1 to MRS-V.

\section{References}

Buffrénil, V., \& de Mazin, J.-M. (1990). Bone histology of the Ichthyosaurs: Comparative data and functional interpretation. Paleobiology, 16(4), 435-447.

Buffrénil, V., \& de Schoevaert, D. (1988). On how the periosteal bone of the delphinid humerus becomes cancellous: Ontogeny of a histological specialization. Journal of Morphology, 198(2), 149-164.

Bürgin, T., Rieppel, O., Sander, M., \& Tschanz, K. Y. (1989). TriasFossilien aus dem Ur-Mittelmeer. Spektrum der Wissenschaft, 8, $110-119$.

Canoville, A., \& Laurin, M. (2010). Evolution of humeral microanatomy and lifestyle in amniotes, and some comments on paleobiological inferences. Biological Journal of the Linnean Society, 100, 384-406.

Carroll, R. L., \& Gaskill, P. (1985). The nothosaur pachypleurosaurus and the origin of plesiosaurs. Philosophical Transactions of the Royal Society of London Series B Biological Sciences, 309(1139), 343-393.

Castanet, J., Francillon-Vieillot, H., Meunier, F. J., \& de Ricqlès, A. (1993). Bone and individual aging. In B. K. Hall (Ed.), Bone: Vol. 7. Bone Growth-B (pp. 245-283). Boca Raton, FL: CRC Press.
Chinsamy, A., \& Raath, M. A. (1992). Preparation of fossil bone for histological examination. Palaeontologica Africana, 29, 39-44.

Cubo, J., Legendre, P., de Ricqlès, A., Montes, L., de Margerie, E., Castanet, J., \& Desdevises, Y. (2008). Phylogenetic, functional, and structural components of variation in bone growth rate of amniotes. Evolution \& Development, 10(2), 217-227.

Cubo, J., Ponton, F., Laurin, M., de Margerie, E., \& Castanet, J. (2005). Phylogenetic signal in bone microstructure of Sauropsids. Systematic Biology, 54(4), 562-574.

de Ricqlès, A. (1976). Recherches paleohistologiques sur les os longs des tetrapodes VII. Sur le classification, la signification fonctionelle et l'histoire des tissus osseux des tetrapodes. Annales de Paléontologie, 62, 71-126.

de Ricqlès, A., \& de Buffrénil, V. (2001). Bone histology, heterochronies and the return of tetrapods to life in water: W[h]ere are we? In J. M. Mazin \& V. de Buffrénil (Eds.), Secondary adaptation of tetrapods to life in water (pp. 289-310). München: Verlag Dr. Friedrich Pfeil.

de Ricqlès, A., Padian, K., Knoll, F., \& Horner, J. R. (2008). On the origin of high growth rates in archosaurs and their ancient relatives: Complementary histological studies on Triassic archosauriforms and the problem of a "phylogenetic signal" in bone histology. Annales de Palaeontologie, 94, 57-76.

Francillon-Vieillot, H., de Buffrénil, V., Géraudie, J., Meunier, F. J., Sire, J. Y., Zylberberg, L., \& de Ricqlès, A. (1990). Microstructure and mineralization of vertebrate skeletal tissues. In J. G. Carter (Ed.), Skeletal biomineralization-patterns, process and evolutionary trends (pp. 471-530). New York: Van Nostrand Reinhold.

Furrer, H. (1995). The Kalkschieferzone (Upper Meride Limestone) near Meride (Canton Ticino, Southern Switzerland) and the evolution of a Middle Triassic intraplatform basin. Eclogae Geologae Helvetica, 88(3), 827-852.

Germain, D., \& Laurin, M. (2005). Microanatomy of the radius and lifestyle in amniotes (Vertebrata, Tetrapoda). Zoologica Scripta, 34(4), 335-350.

Girondot, M., \& Laurin, M. (2003). Bone profiler: A tool to quantify, model, and statistically compare bone-section compactness profiles. Journal of Vertebrate Paleontology, 23(2), 458-461.

Hänni, K. (2004). Die Gattung Ceresiosaurus-Ceresiosaurus calcagnii PEYER und Ceresiosaurus lanzi n. sp. (Lariosauridae, Sauropterygia). PhD thesis. vdf Hochschulverlag AG an der ETH Zürich.

Horner, J. R., Padian, K., \& de Ricqlès, A. (2001). Comparative osteohistology of some embryonic and perinatal archosaurs: Developmental and behavioral implications for dinosaurs. Paleobiology, 27(1), 39-58.

Horner, J. R., de Ricqlès, A., \& Padian, K. (2000). Long bone histology of the hadrosaurid dinosaur Maiasaura peeblesorum: Growth dynamics and physiology based on an ontogenetic series of skeletal elements. Journal of Vertebrate Paleontology, 20, $115-129$.

Houssaye, A. (2010). A new aquatic pythonomorph (Reptilia, Squamata) from the Turonian (Late Cretaceous) of France. Comptes Rendus Palevol, 9, 39-45.

Hugi, J., Scheyer, T. M., Klein, N., Sander, P. M., \& SánchezVillagra, M. R. (2011). Long bone microstructure gives new insights into the life history data of pachypleurosaurids from the Middle Triassic of Monte San Giorgio, Switzerland/Italy. Comptes Rendus Palevol, 10, 413-426. doi:10.1016/j.crpv.2011. 03.009

Klein, N. (2010). Long bone histology of Sauropterygia from the lower Muschelkalk of the Germanic basin provides unexpected implications for phylogeny. PLOS ONE, 5(7), e11613.

Kolb, C., Sanchez-Villagra, M. R., \& Scheyer, T. M. (2011). The palaeohistology of the basal ichthyosaur Mixosaurus Baur, 1887 
(Ichthyopterygia, Mixosauridae) from the Middle Triassic: Palaeobiological implications. Comptes Rendues Palevol, 10, 403-411. doi:10.1016/j.crpv.2010.10.008.

Krahl, A., Sander, P. M., \& Klein, N. (2009). Long bone histology of Middle Triassic eusauropterygians (Nothosauria and Pistosauria) and its implications for paraxial swimming. Journal of Vertebrate Paleontology, 29, 129A.

Müller, J., Scheyer, T. M., Head, J. J., Barrett, P. M., Werneburg, I., Ericson, P. G. P., Oikm, D., \& Sánchez-Villagra, M. R. (2010). The evolution of vertebral numbers in recent and fossil amniotes: The roles of homeotic effects and somitogenesis. PNAS, 107(5), 2118-2123.

Padian, K., de Ricqlès, A. J., \& Horner, J. R. (2001). Dinosaurian growth rates and bird origins. Nature, 412, 405-408.

Parrish, J., Ziegler, A. M., \& Scotese, C. R. (1982). Rainfall patterns and the distribution of coals and evaporites in the Mesozoic and Cenozoic. Palaeogeography Palaeoclimatolology Palaeoecology, 40, 67-101.

Peyer, B. (1931). Die Triasfauna der Tessiner Kalkalpen, IV Ceresiosaurus calcagnii nov. gen. nov. spec. Abhandlungen der Schweizerischen Palaeontologischen Gesellschaft, 51, 1-68.

Peyer, B. (1932). Die Triasfauna der Tessiner Kalkalpen, V. Pachypleurosaurus edwardsii Corn. spec. Abhandlungen der Schweizerischen Palaeontologischen Gesellschaft, Band LII, 3-18.

Ray, S., Botha, J., \& Chinsamy, A. (2004). Bone histology and growth patterns of some nonmammalian therapsids. Journal of Vertebrate Paleontology, 24, 634-648.

Rieppel, O. (1989). A new pachypleurosaur (Reptilia: Sauropterygia) from the Middle Triassic of Monte San Giorgio, Switzerland. Philosophical Transactions of the Royal Society of London B, $323,1-73$.

Rieppel, O. (2000). Chapter 12: Sauropterygia. In O. Kuhn \& P. Wellnhofer (Eds.), Handbuch der Paläoherpetologie/Handbook of Paleoherpetology (pp. 1-134). München: Verlag Dr. Friedrich Pfeil.

Rieppel, O. (2001). Marine reptiles from the Triassic of the Tre Venezie Area, Northeastern Italy. Geology, 44(New series), $1-22$.
Röhl, H. J., Schmid-Röhl, A., Furrer, H., Frimmel, A., Oschmann, W., \& Schwark, L. (2001). Microfacies, geochemistry and palaeoecology of the Middle Triassic Grenzbitumenzone from Monte San Giorgio (Canton Ticino, Switzerland). Geologica Insubrica, 6(1), 1-13.

Sander, P. M. (1989). The pachypleurosaurids (Reptilia: Nothosauria) from the Middle Triassic of Monte San Giorgio (Switzerland) with the description of a new species. Philosophical Transactions of the Royal Society of London B Biological Sciences, 325(1230), 561-666.

Scheyer, T. M., Klein, N., \& Sander, P. M. (2010). Developmental palaeontology of Reptilia as revealed by histological studies. Seminars in Cell \& Developmental Biology, 21(4), 462-470.

Sheldon, A. (1997). Ecological implications of Mosaur bone microstructure. In J. Callaway \& E. Nicholls (Eds.), Ancient marine reptiles (pp. 333-354). Academic Press: London.

Stein, K., \& Langer, M. C. (2009). The long bone histology of the stem sauropodomorph Saturnalia tupiniquim, implications for the early evolution of dinosaur bone microstructure. Journal of Vertebrate Paleontology, 29, 185A.

Taylor, M. A. (2000). Functional significance of bone ballast in the evolution of buoyancy control strategies by aquatic tetrapods. Historical Biology, 14, 15-31.

Waskow, K., \& Sander, P. M. (2011). Bone histology of the dorsal rib of the Jurassic sauropod Camarasaurus: Implications for growth, sexual maturity and longevity. In First international symposium on paleohistology, ISPH 2011, July 18-20, Sabadell (Vol. 1, p. 52).

Wiffen, J., de Buffrénil, V., de Ricqlès, A., \& Mazin, J. M. (1995). Ontogenetic evolution of bone structure in Late Cretaceous Plesiosauria from New Zealand. Geobios, 28(5), 625-640.

Zangerl, R. (1935). Pachypleurosaurus edwardsii, Cornalia, Osteologie, Variationsbreite, Biologie. In B. Peyer (Ed.), Trias Fauna der Tessiner Kalkalpen IX, Pachypleurosaurus. Abhandlungen der Schweizerischen Paläontologischen Gesellschaft/Mémoires de la Société Paléontologique Suisse, 66, 1-80.

Zug, G. R., \& Rand, A. S. (1987). Estimation of age in nesting female Iguana iguana: Testing skeletochronology in a tropical lizard. Amphibia-Reptilia, 8, 237-250. 